\title{
Mineral waters in rheumatoid arthritis
}

Tiago Borges

Centro Hospitalar São João, Porto, Portugal

\section{Abstract}

Background: Rheumatoid arthritis (RA) is an autoimmune disorder affecting nearly $1 \%$ of adult population. First-line therapies include disease-modifying antirheumatic drugs, but creno-balneotherapy is often prescribed in rheumatic disorders and RA is no exception.

Objectives: To know the efficacy of creno-balneotherapy in RA.

Methods: A Medline based search was made using MeSH terms "balneology" and "rheumatoid arthritis". Articles concerning the use of mineral waters in RA treatment were included.

Results: In RA, two traditional ways of employing mineral waters are commonly used: immersion and peliotherapy. Each owns their benefits to non-specific or hydrotherapeutic effects and specific or crenotherapeutic effects. Mineral waters must be regarded as an adjuvant therapy in quiescent, stable or non-progressive RA. Significant benefits have been accomplished with radonenriched and sulphurous waters. Isothermal or hyperthermal waters should be preferred.

Conclusions: Although there is a global lack of evidence, mineral waters are a safe and effective therapy to be considered in RA.

Keywords: rheumatoid arthritis, balneology, mineral waters 


\section{Introduction}

Rheumatoid arthritis (RA) is a chronic autoimmune disease affecting nearly $1 \%$ of adult population with an estimated incidence of 20-50 per 100000 annually. ${ }^{1-3}$ Women after their forth decade of life are mostly affected. ${ }^{2,4}$

There is a concordance rate of $15-30 \%$ among monozygotic twins and 5\% among dizygotic twins, but the genetic role is also based on the association between HLA-DRB1 and positivity for rheumatoid factor (RF) or anticitrullinated protein antibody (ACPA). ${ }^{5}$ These are usually implied in RA pathogenesis and about $50 \%$ of the risk is thought to be linked to genetic causes. ${ }^{6,7}$ Other risk factors include nulliparity, pregnancy (elevated risk 12 months after labor), hormonal imbalance, high birth weight, tobacco, and possibly, low vitamin D intake and/or infections. ${ }^{7}$ Omega 3 fatty acids, mediterranean diet, fruits and vitamin $\mathrm{C}$ seem to add some protection, while certain occupational exposures (silica dust or mineral oils) and red meat often aggravate symptoms. ${ }^{8}$ Meanwhile, immune complex formation during infections can induce RA and, specifically, periodontitis may play a role in RA pathogenesis.

As a typical inflammatory arthritis that involves small joints of hands and feet, RA is characterized by inflammation of synovium, morning stiffness, rheumatoid nodules, presence of RF, radiographic erosions and periarticular osteopenia in hands and/or wrists. ${ }^{4,10}$ It has an initial insidious course in about $60 \%$ but its manifestations can be either articular or systemic. ${ }^{11}$ Progression may follow a monocyclic $(20 \%)$, polycyclic $(70 \%)$ or progressive $(10 \%)$ pattern. $^{7}$ The 2010 RA classification criteria require the presence of clinically established synovitis in at least one joint with no other plausible explanation. ${ }^{12}$

Systemic manifestations are thought to occur in about $40 \%$ of cases. ${ }^{5,7}$ But the RA paradigm corresponds to joint disease where inflammation depends on interactions among macrophages, lymphocytes, fibroblasts and other cells of the inflamed synovium, but also on cell interaction through direct contact or secreted mediators such as interleukins (IL) 1, 6 and tumor necrosis factor $\alpha .^{3}$

There is no cure for RA. Its treatment aims to achieve and maintain a remission state using disease-modifying antirheumatic drugs or biologic treatments. ${ }^{4,11}$ Association therapies with methotrexate seem to be effective in slowing structural damage, while steroids, non-steroidal anti-inflammatory drugs and physical or occupational therapy are important adjuvants in functional rehabilitation and pain relief. ${ }^{4}$

Creno-balneotherapy, either in association with exercise or alone, is prescribed in all forms of arthritis, in which rheumatoid and psoriatic are more frequent. ${ }^{13}$ Muscular tonus, joint mobility and pain intensity are influenced by physiological changes (diuresis, natriuresis, vasodilatation and elevation in cardiac output) that are induced by thermal and hydrological stimuli, although its mechanisms are not well studied. ${ }^{14}$

This article aims to evaluate the efficacy of creno-balneotherapy in RA, focusing on indications, contra-indications and safety of mineral waters. In order to accomplish these goals, a Medline based search was conducted using MeSH terms "balneology" and "rheumatoid arthritis" and articles regarding the use of mineral waters in RA treatment were included.

\section{Peliotherapy}

There are two common ways to use mineral waters: external (immersion, evaporation or peliotherapy) or internal use (ingestion or inhalation). ${ }^{15,16}$

Mud applications use solid vehicles to take advantage of mineral waters. The moisture is formed by three components (telluric, hydrothermal and biological), being used after a maturation phase of several months. ${ }^{17}$

Muds own their benefits to non-specific, hydrotherapeutic effects (common to simple baths in hot tap water) and to specific, crenotherapeutic effects that are consistent with the chemical properties of each mineral water. Thermal effects rely on the influence of hot stimuli on muscle tone and pain intensity. This happens through fast elevations of serum $\beta$-endorphin that probably explain the tolerance to mud treatment, the release of adrenocorticotrophic hormone (ACTH), cortisol, prolactin and growth hormone with no change in their circadian rhythm, and probably immune system modulation. ${ }^{18}$ The last effect is caused by increases in mobility, phagocytic and bactericidal properties and enzymatic activity of granulocytes. Thermal stimulation may also increase the extensibility of collagen-rich tissues and therefore reduce muscular associated contraction. $^{18}$

In contrast to immersion techniques, chemical benefits are more evident with mud packs: one in vitro study has demonstrated that some mud solutes can penetrate full-skin thickness and achieve deeper tissues at quantities with established effects on spontaneous contractility activity of smooth cells. ${ }^{18}$ 
A suppression of the immune system has been described in healthy volunteers. Despite increasing pro-inflammatory cytokines IL-6 and IL-1 $\beta$ with moderate increases of skin temperature, exposure to hyperthermal waters $\left(40-41^{\circ} \mathrm{C}\right)$ leads to significant reductions of circulating levels of T-lymphocytes and eosinophiles which may result from cell redistribution secondary to ACTH and cortisol release. The production of other cytokines like IL2 and IFN- $\gamma$ is also significantly inhibited by sulphurous waters, making memory $\mathrm{T}$ cells their hypothetic target. In healthy subjects or patients with chronic inflammatory diseases, sulphurous waters have a dose-dependent inhibitory effect on the blast transformation and proliferation of $\mathrm{T}$ lymphocytes. Studies conducted in other rheumatic disorders have shown an increase in
IGF-1 and TGF- $\beta$ levels and a reduction in metalloproteinase 3 , prostaglandin E2, nitric oxide and leukotriene B4. ${ }^{18,19}$

Sulphurous waters have an in vitro antioxidant benefit by reducing nitrogen and oxygen reactive species. Experimental studies in rat models of arthritis have shown that mud applications significantly reduce edema, circulating TNF- $\alpha$ and IL-1 $\beta$ levels, synovial hyperplasia, vascularization and cell infiltrates. ${ }^{18}$

Several randomized prospective trials evaluated the efficacy of peliotherapy in RA (see Tables 1 and 2). Others have suggested that their benefits may be less pronounced in patients with low baseline levels of T-lymphocytes, but even low-temperature peloids may be useful in degrees of activity II and III. ${ }^{20-22}$

Table 1: Prospective randomized trials evaluating the efficacy of muds in rheumatoid arthritis

\begin{tabular}{|c|c|c|c|c|c|c|}
\hline & $\begin{array}{l}\text { Treatment } \\
\text { duration }\end{array}$ & $\mathrm{N}$ & Study design & Outcomes & Results & $\begin{array}{c}\text { FU } \\
\text { months }\end{array}$ \\
\hline $\begin{array}{l}\text { Svarcová } \\
\text { et al } \\
1990^{23}\end{array}$ & Unknown & 45 & $\begin{array}{c}\text { Group I }(\mathrm{N}=15) \text { : } \\
\text { Hot tub } \\
\text { Group II }(\mathrm{N}=15) \text { : } \\
\text { massagem de pressão } \\
\text { alternada } \\
\text { Group III }(\mathrm{N}=15): \\
\text { muds } \\
\text { No randomization }\end{array}$ & $\begin{array}{l}\text { Ankle mobility } \\
\text { Clinical evaluation of } \\
\text { efficacy }\end{array}$ & $\begin{array}{l}\text { More notorious } \\
\text { improvements in Groups I } \\
\text { and III }\end{array}$ & None \\
\hline $\begin{array}{l}\text { Sukenik et } \\
\text { al } 1992^{24}\end{array}$ & 2 weeks & 28 & $\begin{array}{l}\text { Group I }(\mathrm{N}=14) \text { : } \\
\text { mud compresses } \\
\text { Group II }(\mathrm{N}=14) \text { : } \\
\text { attenuated mud } \\
\text { compresses } \\
\text { Randomized }\end{array}$ & $\begin{array}{l}\text { Morning stiffness } \\
\text { Manual grip strength } \\
\text { Daily activities } \\
\text { Self-assessment } \\
\text { activity } \\
\text { Number of active joints } \\
\text { Ritchie index }\end{array}$ & $\begin{array}{l}\text { Significant improvement } \\
(\mathrm{p}<0.01 \text { or } \mathrm{p}<0.05) \text { in } \\
\text { Group I for the majority of } \\
\text { outcomes, between first to } \\
\text { third months of FU }\end{array}$ & 3 \\
\hline $\begin{array}{l}\text { Codish et } \\
\text { al } 2005^{25}\end{array}$ & 3 weeks & 45 & $\begin{array}{l}\text { Group I }(\mathrm{N}=22) \text { : } \\
\text { true mud compresses } \\
\text { (and Dead Sea } \\
\text { climatotherapy) } \\
\text { Group II }(\mathrm{N}=23) \text { : } \\
\text { attenuated mud } \\
\text { compresses (and } \\
\text { Dead Sea } \\
\text { climatotherapy) } \\
\text { Randomized }\end{array}$ & $\begin{array}{l}\text { Number of painful or } \\
\text { swollen joints } \\
\text { Clinical evaluation of } \\
\text { activity (BASDAI) } \\
\text { Self-assessment of } \\
\text { severity } \\
\text { Pain (VAS) } \\
\text { Mobility (VAS) } \\
\text { Qualidade de vida (SF- } \\
\text { 36) }\end{array}$ & $\begin{array}{l}\text { Significant reduction at } 3^{\text {rd }} \text {, } \\
4^{\text {th }} \text { and } 12^{\text {th }} \text { weeks in } \\
\text { Groups I and II } \\
\text { Significant improvement in } \\
\text { Group I }(p=0.002) \text { and II } \\
(p=0.002) \text { without } \\
\text { differences between both } \\
\text { Significant reduction at } 3^{\text {rd }} \\
\text { and } 4^{\text {th }} \text { weeks in Groups I } \\
\text { and II } \\
\text { Significant improvement in } \\
\text { Group I (p }=0.002 \text { ) and II } \\
\text { (p = } 0.002 \text { ) without } \\
\text { differences between both } \\
\text { Significant improvement in } \\
\text { Group I (p =0.011) and II } \\
\text { (p = } 0.011 \text { ) without } \\
\text { differences between both } \\
\text { Significant improvement in } \\
\text { pain relief in Group I }\end{array}$ & 3 \\
\hline
\end{tabular}


Table 2: Prospective randomized trials evaluating the efficacy of peliotherapy and immersion with mineral waters in rheumatoid arthritis

\begin{tabular}{|c|c|c|c|c|c|c|}
\hline & $\begin{array}{l}\text { Treatment } \\
\text { duration }\end{array}$ & $\mathrm{N}$ & Study design & Outcomes & Results & FU \\
\hline \multirow[t]{9}{*}{$\begin{array}{l}\text { Sukenik et } \\
\text { al } 1990^{14}\end{array}$} & \multirow[t]{9}{*}{2 weeks } & \multirow[t]{9}{*}{40} & \multirow{3}{*}{$\begin{array}{l}\text { Group I }(\mathrm{N}=10) \text { : } \\
\text { daily mud packs }\end{array}$} & $\begin{array}{l}\text { Duration of morning } \\
\text { stiffness (minutes) }\end{array}$ & $\begin{array}{l}\text { Significant improvement in } \\
\text { group II }(\mathrm{p}<0.05) \text { and } 4(\mathrm{p}<\end{array}$ & \multirow[t]{9}{*}{$\begin{array}{c}3 \\
\text { months }\end{array}$} \\
\hline & & & & $\begin{array}{l}\text { 15-meter walk time } \\
\text { (seconds) }\end{array}$ & $\begin{array}{l}\text { Significant improvement in } \\
\text { group I }(\mathrm{p}<0.05) \text {, II }(\mathrm{p}<0.05) \\
\text { and III }(\mathrm{p}<0.01) \text { at first month }\end{array}$ & \\
\hline & & & & $\begin{array}{l}\text { Hand grip strength } \\
(\mathrm{mmHg})\end{array}$ & $\begin{array}{l}\text { Significant improvement in } \\
\text { group I }(p<0.05) \text {, II }(p<0.05) \\
\text { and III }(p<0.01) \text { at first month }\end{array}$ & \\
\hline & & & $\begin{array}{l}\text { daily hot sulphur } \\
\text { baths }\end{array}$ & $\begin{array}{l}\text { Circumferences of the } \\
\text { proximal }\end{array}$ & $\begin{array}{l}\text { Significant improvement in } \\
\text { group I }(\mathrm{p}<0.01) \text {, II }(\mathrm{p}<0.05)\end{array}$ & \\
\hline & & & Group III $(\mathrm{N}=10)$ : & $\begin{array}{l}\text { interphalangeal joints } \\
\text { of the hand }(\mathrm{mm})\end{array}$ & and IV $(\mathrm{p}<0.05)$ at 3 months & \\
\hline & & & $\begin{array}{l}\text { packs and hot sulphur } \\
\text { baths }\end{array}$ & Activities of daily living & $\begin{array}{l}\text { Significant improvement in } \\
\text { group I and IV }(p<0.05) \text { at } 3 \\
\text { months }\end{array}$ & \\
\hline & & & $\begin{array}{l}\text { Group IV }(\mathrm{N}=10) \text { : } \\
\text { control group }\end{array}$ & $\begin{array}{l}\text { Patient assessment of } \\
\text { severity of disease }\end{array}$ & $\begin{array}{l}\text { Significant improvement in } \\
\text { group I }(p<0.01) \text {, II }(p<0.05) \\
\text { and }(p<0.05) \text { at } 3 \text { months }\end{array}$ & \\
\hline & & & $\begin{array}{l}\text { Randomized plus } \\
\text { observer blinded }\end{array}$ & Number of active joints & $\begin{array}{l}\text { Significant improvement in } \\
\text { group I }(\mathrm{p}<0.01) \text {, II }(\mathrm{p}<0.05) \\
\text { and III }(\mathrm{p}<0.05) \text { at } 3 \text { months }\end{array}$ & \\
\hline & & & & Ritchie index & $\begin{array}{l}\text { Significant improvement in } \\
\text { group I }(\mathrm{p}<0.01) \text {, II }(\mathrm{p}<0.01) \text {, } \\
\text { III }(\mathrm{p}<0.05) \text { and IV }(\mathrm{p}<0.05) \\
\text { at } 3 \text { months }\end{array}$ & \\
\hline \multirow[t]{7}{*}{$\begin{array}{l}\text { Elkayam et } \\
\text { al } 1991^{26}\end{array}$} & \multirow[t]{7}{*}{2 weeks } & \multirow[t]{7}{*}{41} & $\begin{array}{l}\text { Group I }(\mathrm{N}=19) \text { : } \\
\text { mineral baths (saline } \\
\text { and sulphated) and }\end{array}$ & Ritchie index & $\begin{array}{l}\text { Temporary improvement in both } \\
\text { groups between } 2^{\text {nd }} \text { and } 8^{\text {th }} \\
\text { weeks of } F U(p<0.05)\end{array}$ & \multirow[t]{7}{*}{$\begin{array}{c}3 \\
\text { months }\end{array}$} \\
\hline & & & $\begin{array}{l}\text { mud packs (at } 38^{\circ} \mathrm{C} \\
\text { for } 20 \text { minutes each) }\end{array}$ & Hand grip strength & $\begin{array}{l}\text { Improvement in group I (p }< \\
0.05 \text { ) sustained for } 3 \text { months }\end{array}$ & \\
\hline & & & Group II $(\mathrm{N}=22)$ : tap & Patient and clinical & Improvement until 2 weeks of & \\
\hline & & & water baths (at $38^{\circ} \mathrm{C}$ & assessment of activity & FU in both groups $(\mathrm{p}<0.05)$ & \\
\hline & & & for 20 minutes) & Morning stiffness & No improvement & \\
\hline & & & Randomized and & 15-meter walk time & No improvement & \\
\hline & & & patient-blinded & Laboratory values & No improvement & \\
\hline \multirow[t]{3}{*}{$\begin{array}{l}\text { Mustur et al } \\
2008^{27}\end{array}$} & \multirow[t]{3}{*}{4 weeks } & \multirow[t]{3}{*}{69} & $\begin{array}{l}\text { Peliotherapy } \\
\text { Immersion }\end{array}$ & $\begin{array}{l}\text { Functional capacity } \\
\text { (MHAQ) }\end{array}$ & $\begin{array}{l}\text { Significant improvement }(p< \\
0.01)\end{array}$ & \multirow[t]{3}{*}{28 days } \\
\hline & & & Kinesiotherapy & Quality of life (SF-36) & & \\
\hline & & & Electrotherapy & & $\begin{array}{l}\text { Significant improvement }(p< \\
0.01) \text { in both parameters }\end{array}$ & \\
\hline \multirow[t]{3}{*}{$\begin{array}{l}\text { Stojanović } \\
\text { et al } 2009^{28}\end{array}$} & \multirow[t]{3}{*}{$\begin{array}{l}14.7+/- \\
4.8 \text { days }\end{array}$} & \multirow[t]{3}{*}{73} & $\begin{array}{l}\text { Peliotherapy } \\
\text { Immersion }\end{array}$ & $\begin{array}{l}\text { Functional capacity } \\
\text { (HAQ) }\end{array}$ & $\begin{array}{l}1.07+/-0.61 \text { vs } 0.86+/-0.55(\mathrm{p} \\
<0.05) \text { após tratamento }\end{array}$ & \multirow[t]{3}{*}{28 days } \\
\hline & & & Kinesiotherapy & Quality of life (QOL- & $\begin{array}{l}5.38+/-1.62 \text { vs } 7.35+/-1.81(\mathrm{p} \\
<0.05) \text { anós tratamento }\end{array}$ & \\
\hline & & & Electromerapy & $\begin{array}{l}\text { Activity of disease } \\
\text { (DAS) }\end{array}$ & $\begin{array}{l}6.30+/-0.81 \text { vs } 5.48+/-0.75(\mathrm{p} \\
<0.001) 28 \text { dias após tratamento }\end{array}$ & \\
\hline
\end{tabular}

FU - follow-up; MHAQ - Modified Health Assessment Questionnaire; SF-36 - Medical Outcomes Study Short Form 36-item Questionnaire; HAQ - Health Assessment Questionnaire; QOL-RA - Quality of Life Rheumatoid Arthritis; DAS - Disease Activity Score 


\section{Immersion}

Mineral baths are of great value in traumatology and rheumatology, mostly in the treatment of disorders like scoliosis, osteoarthritis and other kinds of arthritis: for this effect, isothermal (at $34-35^{\circ} \mathrm{C}$ ) waters are often preferred. $^{29,30}$

Balneotherapy owns its effects in RA to mechanical, thermal and chemical effects through skin contact, even though cutaneous absorption of mineral solutes seems to be limited. Two kinds of effects must be distinguished: non-specific or hydrotherapeutic and specific or crenotherapeutic effects. $^{31}$ Two randomized controlled trials suggested that RA patients are more likely to report a wellbeing sensation when submitted to hydrotherapy instead of land exercises, in spite of non-significant differences in terms of pain, functional scores or quality of life. ${ }^{32,33}$ In the past, the benefits of hydrotherapy in RA have been recognized for diminishing the circumference of proximal interphalangeal joints and enhancing diuresis, kaliuresis and natriuresis. ${ }^{14}$ Some authors think that the efficacy of crenobalneotherapy in RA is due to these effects, while others find biomechanical effects a plausible explanation. $^{13}$

In mechanical terms, immersion can be benefic in terms of joint mobility, muscle tone and pain intensity. ${ }^{18}$ It takes advantage of the hydrostatic pressure which augments with water concentration, allowing increases in diuresis, natriuresis and cardiac output through distension of volume receptors caused by central hypervolemia. $^{18,31}$

The effects of immersion also correlate to temperature: hot stimuli seem to reduce muscle spasm and increase the pain threshold, probably with more ACTH, cortisol, prolactin and $\mathrm{GH}$ release. Besides, the consequences at hypothalamus-pituitary-adrenal axis seem to be relevant by conditioning the anti-inflammatory and anti-edema effects of steroids and, as in peliotherapy, a cutaneous overproduction of endorphins and its precursor proopiomelanocortin (POMC) can occur. ${ }^{18}$

Chemical effects of mineral waters in RA are less clear, being secondary to skin penetration of thermal solutes that probably depends on temperature and duration of immersion. ${ }^{18}$ These effects include the anti-inflammatory benefit, best studied in dermatological diseases. ${ }^{34}$ During balneotherapy, RA patients change their serological immune profile, presenting a slightly defensive condition which is translated by modifications in $\gamma$-globulin, C-reactive protein and $\alpha 1$-glicoprotein. ${ }^{35}$

Alkaline or saline mineral waters may have a beneficial effect on the formation of free radicals that was demonstrated by reductions in catalase, superoxide dismutase, malondialdehyde and glutathione peroxidase levels after balneotherapy. ${ }^{36}$ Besides, mineral waters may induce changes in serotonin transporter in healthy volunteers that may explain wellness sensation. ${ }^{37}$ Studies conducted in other rheumatic diseases have demonstrated similar anti-inflammatory effects to those described for peliotherapy.

Mineral waters are considered to be radon-enriched when its concentration surpasses 18 nanocuries. $^{38}$ Radon is probably an active therapeutic substance, since its alpha-particles stimulate the release of anti-inflammatory cytokines (TGF- $\beta$ and IL-10), already documented with UV-B and low dose X-rays. ${ }^{39}$ The skin is likely to absorb radon, activating local processes common to topical steroids' use and enhancing the ability to repair DNA and normalize the "killer" function of cells which is reduced in rheumatic disorders. ${ }^{40}$ In these diseases, studies evaluating the efficacy of mineral waters have shown more pronounced effects at medium or long term in favor of radon rather than at the end of treatment. ${ }^{39}$

Some prospective randomized trials have evaluated the efficacy of mineral water immersion in RA (see Tables 2 and 3). A review concluded that radon-carbon dioxide baths may not lead to any difference in pain on the short-term when comparing to $\mathrm{CO}_{2}$-baths. Sulphurous waters have also not shown to induce a significant improvement in wellness sensation when compared to lack of treatment, but a significant benefit was found in pain relief at 8 weeks in comparison to cyclosporine (relative risk $=2.4$ ) that is insufficient to recommend balneotherapy in monotherapy. ${ }^{41}$ 
Table 3: Prospective trials evaluating the efficacy of mineral baths in rheumatoid arthritis

\begin{tabular}{|c|c|c|c|c|c|c|}
\hline & $\begin{array}{l}\text { Treatmen } \\
t \text { duration }\end{array}$ & $\mathrm{N}$ & Study design & Outcomes & Resuts & $\begin{array}{c}\text { FU } \\
\text { months }\end{array}$ \\
\hline $\begin{array}{l}\text { Günther et al } \\
1976^{42}\end{array}$ & Unknown & 20 & $\begin{array}{l}\text { Group I }(\mathrm{N}=10): \\
\text { radon-enriched baths } \\
\text { Group II }(\mathrm{N}=10): \\
\text { tap water baths } \\
\text { Not randomized, with } \\
\text { crossover }\end{array}$ & $\begin{array}{l}\text { Hand grip strength, } \\
\text { Joint circumference, } \\
\text { Joint mobility, Pain }\end{array}$ & 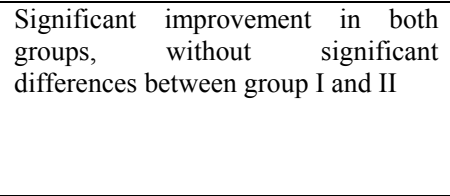 & No \\
\hline $\begin{array}{lll}\text { Steiner } & \text { et al } \\
1979^{43} & & \end{array}$ & Unknown & 24 & $\begin{array}{c}\text { Group I }(\mathrm{N}=12): \\
\text { tap water plus exercises } \\
\text { plus electrotherapy } \\
\text { Group II }(\mathrm{N}=12): \\
\text { thermal baths plus } \\
\text { exercises plus massages } \\
\text { Not randomized, with } \\
\text { crossover }\end{array}$ & $\begin{array}{l}\text { Morning stiffness, X- } \\
\text { rays, Pain, Joint } \\
\text { circumference, } \\
\text { Number of active } \\
\text { joints, Joint mobility, } \\
\text { ADL }\end{array}$ & Significant improvement in group II & 12 \\
\hline $\begin{array}{l}\text { Sukenik et al } \\
1990^{44}\end{array}$ & 2 weeks & 30 & $\begin{array}{c}\text { Group I }(\mathrm{N}=15): \\
\text { daily Dead Sea baths } \\
\text { Group } 2(\mathrm{~N}=15): \\
\text { saline baths } \\
\text { Randomized and double- } \\
\text { blinded }\end{array}$ & $\begin{array}{l}\text { Morning stiffness, } \\
\text { Walk time, Hand grip } \\
\text { strength, Joint } \\
\text { circumference, ADL, } \\
\text { Patient assessment of } \\
\text { disease activity, } \\
\text { Number of active } \\
\text { joints, Ritchie index, } \\
\text { Laboratory values } \\
\end{array}$ & $\begin{array}{l}\text { Significant improvement }(\mathrm{p}<0.01) \text { in } \\
\text { group I in the majority of outcomes } \\
\text { Maximum effect at the of the } \\
\text { treatment period and sustained for } \\
\text { one month }\end{array}$ & 3 \\
\hline $\begin{array}{l}\text { Landewé et al } \\
1992^{45}\end{array}$ & $\begin{array}{l}12 \text { weeks } \\
(12 \\
\text { sessions })\end{array}$ & 46 & $\begin{array}{l}\text { Group I }(\mathrm{N}=27) \text { : } \\
\text { thermal bath } \\
\text { Group II }(\mathrm{N}=19) \text { : } \\
\text { tap water bath } \\
\text { No randomization }\end{array}$ & $\begin{array}{l}\text { Morning stiffness, } \\
\text { Laboratory values, } \\
\text { Ritchie index, Pain, } \\
\text { ADL }\end{array}$ & $\begin{array}{l}\text { Improvements in both groups, } \\
\text { without significant differences } \\
\text { between group I and II }\end{array}$ & No \\
\hline $\begin{array}{l}\text { Sukenik et al } \\
1995^{46}\end{array}$ & 12 days & 36 & $\begin{array}{c}\text { Group I }(\mathrm{N}=9) \text { : } \\
\text { daily Dead Sea baths } \\
\text { Group II }(\mathrm{N}=9) \text { : } \\
\text { daily sulphur baths } \\
\text { Group III }(\mathrm{N}=10) \text { : } \\
\text { both } \\
\text { Group IV }(\mathrm{N}=8) \text { : control } \\
\text { Randomized plus observer- } \\
\text { blinded }\end{array}$ & 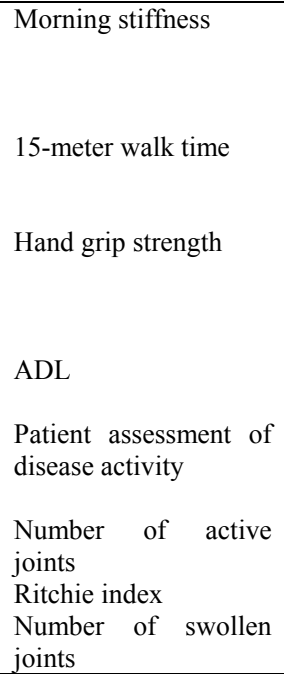 & $\begin{array}{l}\text { Significant improvement in groups I, } \\
\text { II and III ( } p<0.05) \text {, sustained until } 3 \\
\text { months only in group III }(\mathrm{p}<0.05) \\
\text { Significant improvement in group III } \\
(\mathrm{p}<0.01) \text { at } 3 \text { months } \\
\text { Significant improvement in groups I, } \\
\text { II and III ( } \mathrm{p}<0.05 \text { ) at first month; } \\
\text { significant improvement in group I (p } \\
<0.01) \text { at } 3 \text { months } \\
\text { Significant improvement in groups I } \\
\text { and III }(\mathrm{p}<0.05) \text { at } 3 \text { months } \\
\text { Best results in groups I and III but not } \\
\text { sustained beyond the first month (p }< \\
0.05) \\
\text { Significant improvement in groups I e } \\
\text { II }(\mathrm{p}<0.01) \text { at } 3 \text { months } \\
\text { Significant improvement in group III } \\
(\mathrm{p}<0.05) \text { at } 3 \text { months }\end{array}$ & 3 \\
\hline $\begin{array}{lll}\text { Franke } & \text { et } \\
2000^{40} & & \end{array}$ & 4 weeks & 60 & $\begin{array}{l}\text { Group I }(\mathrm{N}=30) \text { : natural } \\
\text { radon and } \mathrm{CO}_{2} \text { baths } \\
\text { Group II }(\mathrm{N}=30) \text { : } \\
\text { artificial } \mathrm{CO}_{2} \text { baths at the } \\
\text { same concentration } \\
\text { Randomized and double- } \\
\text { blinded }\end{array}$ & $\begin{array}{l}\text { Pain (EA100) } \\
\text { Function (AIMS) } \\
\begin{array}{l}\text { SR, CRP, KFI, pain } \\
\text { frequency, morning } \\
\text { stiffness }\end{array}\end{array}$ & $\begin{array}{l}-6.6 \mathrm{~mm} \text { vs. }+9.7 \mathrm{~mm}(16.9 \% \\
\text { reduction after } 6 \text { months in group I, } p \\
=0.04) \\
\text { Improvement in group I after } 6 \\
\text { months: } 0.57(\mathrm{p}=0.01)\end{array}$ & 6 \\
\hline $\begin{array}{l}\text { Franke et al } \\
2007^{39}\end{array}$ & 3 weeks & $\begin{array}{c}13 \\
4\end{array}$ & $\begin{array}{c}\text { Group I }(\mathrm{N}=67): \\
\text { natural radon and } \mathrm{CO}_{2} \\
\text { baths } \\
\text { Group } \mathrm{II}(\mathrm{N}=67): \\
\text { artificial } \mathrm{CO}_{2} \text { baths at the } \\
\text { same concentration } \\
\text { Randomized and double } \\
\text { blinded }\end{array}$ & $\begin{array}{l}\text { Functional capacity } \\
\text { Pain } \\
\text { Steroids consumption }\end{array}$ & $\begin{array}{l}-1.86 \text { vs }-1.99(\mathrm{p}=0,03) \\
\text { RM-ANCOVA: } p \mathrm{GME}=0.15, p \mathrm{GxC} \\
=0.033 \\
-2.46 \text { vs } 2.56(\mathrm{p}=0,09) \\
1.48 \text { vs }-0.33(\mathrm{p}=0,03) \\
\text { RM-ANCOVA: } \quad p \mathrm{GME}=0.064, \\
p \mathrm{GxC}=0.025 \\
+2.28 \text { vs }-10.52(\mathrm{p}=0,01) \\
\text { RM-ANCOVA: } \quad p \mathrm{GME}=0.035, \\
p \mathrm{GxC}=0.008 \quad\end{array}$ & 12 \\
\hline
\end{tabular}




\section{In vitro studies}

Grabsky et al have evaluated the effect of hydrogen sulfide-enriched water on superoxide dismutase in 59 patients (after 5, 10, 15 and 20 minutes of erythrocyte incubation) and found a significant $(\mathrm{p}<0.05)$, temporary (after 5 and 10 minutes) improvement in enzyme activity $(1589.95+/-208.41 \mathrm{U} / \mathrm{gHb}$ in the control group versus $1622.12+/$ - in RA cases). ${ }^{47}$ Later, Marković et al have pointed that the anti-inflammatory benefit of mineral waters in RA may be more dependent on hyperthermia rather than on chemical properties of sulphurous waters. ${ }^{48}$

\section{Indications}

The indications of mineral waters in RA are based on its analgesic, anesthetic, desensitizing, anti-inflammatory, immunomediator and anti-edema effects, but also because it improves metabolic trophic processes and locomotion. ${ }^{17,21}$ Choosing a "thermal cure" must be an individualized process and take into account several factors, including duration, intensity and activity of the disease, RA progression and staging. ${ }^{49}$

According to the French National Authority for Health, creno-balneotherapy is indicated (with grade $\mathrm{C}$ ) in cases of stable, old or non-progressive RA due to its functional and analgesic benefits. ${ }^{50}$ The improvement in functional capacity and quality of life (level 2 of evidence) exists along with an inconsistent comparison between groups in terms of pain, muscular strength and aerobic ability (level 4 of evidence). ${ }^{51}$ In non-progressive forms and postarthritic arthrosis, highly stimulant treatments such as sulphurous immersions or peloids are indicated. ${ }^{49}$ In monotherapy, creno-balneotherapy has been considered (but not discouraged or recommended) in only one physiotherapy guideline and so its role is mainly adjuvant in active or passive exercises. ${ }^{49,52,53}$

Grototherapy is often chosen rather peliotherapy in inflammatory joint diseases, whilst the opposite option is valid in degenerative and posttraumatic disorders. ${ }^{29} \mathrm{RA}$ is an exception, since balneotherapy and subaquatic exercises are useful during the chronic phase when functional limitations must be attenuated, although muds are indicated in advanced, inactive phases of RA, promoting functional rehabilitation of affected joints. ${ }^{29}$ The pool must be deep enough to allow total immersion of the body in order to guarantee that exercises are performed without loadbearing. ${ }^{51}$

As for other rheumatic diseases, the duration of a thermal cure should be superior to 4 weeks because substantial benefits are rarely noted before the third week of treatment. But a 6week duration treatment with at least 3-days a week frequency is acceptable. ${ }^{29}$ At administrative level, there are geographic differences: in Portugal, a thermal cure usually takes 2 to 3 weeks but there is a lack of specificity according to the treated disorder; for example, in Turkey, the duration of 3 or 4 weeks is considered to be more reasonable in diseases such as RA, ankylosing spondylitis and psoriatic arthritis. ${ }^{54}$

In chronic joint diseases, either degenerative or inflammatory, the possibilities for crenotherapeutic use are multiple and sulphurous (at least $0.2 \mathrm{mg} / \mathrm{L}$ of $\mathrm{H}_{2} \mathrm{~S}$ or its anion $\mathrm{HS}^{-}$) waters are mainly indicated, through ingestion or immersion, but only the last is performed in functional rehabilitation. ${ }^{16}$ Sulfide $\left(\mathrm{H}_{2} \mathrm{~S}\right)$ takes part in the composition of essential amino acids that may be present in connective tissues. Rheumatic diseases are considered to be connective tissue disorders, justifying the empirical preference for sulphur in RA. ${ }^{55}$

Carbogaseous, alkaline and saline waters are empirically indicated in joint inflammatory disorders, but radon-enriched waters own a proven effect in rheumatic diseases. ${ }^{15,16,55}$ Despite being able to enhance blood circulation and radon incorporation in the body, carbogaseous waters do not have an isolated anti-rheumatic proven effect. ${ }^{39}$ Meanwhile, iodine water $(1 \mathrm{mg}$ iodine per thousand) has been empirically used in chronic rheumatism management. ${ }^{55}$

Immersion is best tolerated at $34-35^{\circ} \mathrm{C}$ during 20 minutes but more elevated temperatures seem to be at least equally effective. ${ }^{56}$ In peliotherapy, the classic treatment lasts for 12 diary sessions through application of hot muds (at $40-42^{\circ} \mathrm{C}$ ) in affected joints during approximately 20 minutes, followed by thermal immersion (at $36-37^{\circ} \mathrm{C}$ ) during $12-15$ minutes. ${ }^{17}$ Nevertheless, low-temperature muds also induce local antiinflammatory and analgesic effects, inhibiting the immune system, improving locomotion and inducing a trophic metabolic action. ${ }^{21,22}$

In conclusion, sulphurous and radonenriched waters, at isothermal or hyperthermal temperatures, must be first-line options in RA, even though carbogaseous and low-temperature peloids are acceptable. ${ }^{21,22}$

\section{Contraindications and side effects}

General contraindications include advanced atherosclerosis, drug-resistant hypertension, decompensated cardiac disease, advanced respiratory failure, acute or active disease, consumptive disorder (e.g., tuberculosis), malignant cancer, advanced renal failure, cirrhosis 
and severe hepatic failure, as well as severe mental illness. ${ }^{16}$ Therefore, the first four contraindications must be outlined given their high incidence in RA. Increased susceptibility to infections in RA should alert clinicians to the fact that fever contraindicates crenotherapy. ${ }^{16}$ In other hand, local contraindications include severe venous insufficiency and some dermatologic lesions.

Severe cardiovascular diseases are formal contraindications for peliotherapy. ${ }^{29}$ However, compensated heart failure must not hinder a thermal treatment because quality of life and hemodynamic function can be improved. ${ }^{57}$ Equally, mineral waters are not contraindicated in controlled hypertension or obesity. ${ }^{58}$

An acute episode of RA with high activity is an absolute contraindication for thermal stimuli since the priority in these cases is to stop ankylosis and inflammation. As professional agreement, crenotherapy is not indicated in active RA. ${ }^{49,50}$ Specifically, children with any kind of polyarticular arthritis cannot use peloids as therapeutic measure. $^{29}$

Although creno-balneotherapy is usually well tolerated outside exacerbation periods, clinical trials in RA patients have not evaluated it safety ${ }^{41,51}$ Mild cases of thermal reactions have been registered in RA patients, being more usual in active disease. ${ }^{14}$ Stopping treatment is often unnecessary but this decision must be taken at individual basis. ${ }^{51}$ Other adverse effects are related to water temperature (hyperthermia, burns, headaches or epilepsy) and hydrotherapy itself (e.g., Legionella or Pseudomonas infections).

\section{Conclusions}

The recommendations for the use of mineral water in RA are listed in Table 4.

Table 4: Principles for the use of mineral water in RA

- Creno-balneotherapy is indicated in rheumatoid arthritis due to analgesic, anti-edemigenous, anti-inflammatory, miorrelaxant and muscle-trophic effects

- Mineral waters must be regarded as an adjuvant therapy and not as a monotherapy treatment

- Creno-balneotherapy is indicated in quiescent, stable or non-progressive RA

- The choice of a "thermal cure" must be individualized and take into account the intensity, activity, progression and staging of RA

- Immersion and peliotherapy are the modalities to be considered

- Sulphurous or radon-enriched waters must be regarded as first line options due to their proven efficacy in randomized controlled trials

- In empirical terms, carbogaseous, saline or alkaline waters are secondary options to be considered

- In relation to temperature, isothermal or hyperthermal waters must be preferred

- Do not use mineral waters if active disease, fever, uncompensated heart disease, drug-resistant hypertension or severe respiratory failure are present

- $\quad$ Avoid muds in severe cardiovascular diseases or children with RA or others polyarthritis

- $\quad$ Although stopping treatment is not usually necessary, adverse effects must be analyzed at individual basis 
Although the benefits of crenobalneotherapy in pain relief and functional rehabilitation of RA patients have been demonstrated, clinical trials have globally failed in terms of methodological quality. ${ }^{41,59}$ Rare trials have been double blinded or taken in account quality of life as an outcome, which is surprising since this is one of creno-balneotherapy purposes. $^{39,41}$ The inclusion of few patients limits the validity of trials in terms of efficacy and tolerance of mineral waters. Also, duration of treatment has been inferior to that previously referred in ideal scenarios and follow-up is usually brief. In fact, balneotherapeutic benefits in Behçet spondylitis have only been achieved after 40 weeks of follow-up. ${ }^{41}$

Other creno-balneotherapeutic modalities need to be evaluated: grototherapy, inhalation and ingestion are popular amongst patients with endocrine and metabolic disorders and its use in RA is no more than a mystery. ${ }^{41,60}$ In RA, sauna is often used by patients during balneotherapy: in fact, a study enrolling patients with RA and ankylosing spondylitis demonstrated significant reductions in fatigue, pain and joint rigidity with infrared sauna at short term, with reasonable tolerance and no exacerbation of these disorders. ${ }^{61}$ The role of thermal properties, mineral content and tonicity of each water needs to be evaluated, correlating each specificity (mineral content, tonicity and temperature) with effectiveness. It also is important to elucidate how important is the contribution of concomitant therapies such as climatotherapy and dietary changes that are commonly used together with crenotherapy.

The recognition of balneology as an independent medical specialty, as it happens in Turkey, Spain or Italy, or competence, occurring in Portugal, is not universal, as it is not the use of mineral waters in geographical terms. But there are also other obstacles to the global acceptance of creno-balneotherapy: the focus on single methods with a lack of a comprehensive concept, the inexistence of a transversal nomenclature or the use of crenotherapy exclusively with wellness purposes. ${ }^{60}$

It also remains unclear to what extent the benefits of creno-balneotherapy are caused by the relaxing environment or other concomitant nondrug therapies that are commonly used. ${ }^{52}$

\section{References}

1. Bax M, van Heemst J, Huizinga T, Toes R. Genetics of rheumatoid arthritis: what have we learned? Immunogenetics 2011;63:459-66. http://www.ncbi.nlm.nih.gov/pubmed/21556860

2. Carmona L, Cross M, Williams B, Lassere M, March L. Rheumatoid arthritis. Best Pract Res Clin Rheumatol 2010;24:733-45. http://www.ncbi.nlm.nih.gov/pubmed/21665122

3. Kahlenberg J, Fox D. Advances in the medical treatment of rheumatoid arthritis. Hand Clin 2011;27:1120. http://www.ncbi.nlm.nih.gov/pubmed/21176795

4. Firestein G, Budd R, Harris E, McInnes I, Ruddy S, Sergent J. Kelley's Textbook of Rheumatology. 8th ed. Philadelphia: Mosby Elsevier; 2008.

5. McInnes I, Schett G. The pathogenesis of rheumatoid arthritis. N Eng J Med 2011;365:2205-19. http://www.ncbi.nlm.nih.gov/pubmed/22150039

6. Scott D, Wolfe F, Huizinga T. Rheumatoid arthritis. Lancet 2010;376:1094-108. http://www.ncbi.nlm.nih.gov/pubmed/20870100

7. Hochberg M, Silman A, Smolen J, Weinblatt M, Weisman M. Rheumatology. 5th ed. Philadelphia; 2011.

8. Pile K, Kennedy L. Problem Solving in Rheumatology. 1st ed. Oxford: Clinical Publishing; 2008.

9. Detert J, Pischon N, Burmester G, Buttgereit F. The association between rheumatoid arthritis and periodontal disease. Arthritis Res Ther 2010;12:218. http://www.ncbi.nlm.nih.gov/pubmed/21062513

10. Ebert E, Hagspiel K. Gastrointestinal and hepatic manifestations of rheumatoid arthritis. Dig Dis Sci 2011;56:295-302. http://www.ncbi.nlm.nih.gov/pubmed/21203902

11. Imboden J, Hellmann D, Stone J. Rheumatology: Diagnosis \& Treatment 2nd ed; 2006.

12. Corrao S, Calvo L, Licata G. The new criteria for classification of rheumatoid arthritis: what we need to know for clinical practice. Eur $\mathrm{J}$ Intern Med 2011;22:217-9.

http://www.ncbi.nlm.nih.gov/pubmed/21570636

13. Verhagen A, de Vet H, de Bie R, Kessels A, Boers M, Knipschild P. Taking baths: the efficacy of balneotherapy in patients with arthritis. A systematic review. J Rheumatol 1997;24:1964-71. http://www.ncbi.nlm.nih.gov/pubmed/9330940

14. Sukenik S, Buskila D, Neumann L, KleinerBaumgarten A, Zimlichman S, Horowitz J. Sulphur bath and mud pack treatment for rheumatoid arthritis at the Dead Sea area. Ann Rheum Dis 1990;49:99-102. http://www.ncbi.nlm.nih.gov/pubmed/2180388

15. Moss G. Water and health: A forgotten connection? Perspect Public Health 2010;130:227-32. http://www.ncbi.nlm.nih.gov/pubmed/21086819

16. Hipólito-Reis C. [Curas Elementares, Curas Termais \& etc. - em Portugal e na Galiza]. 1st ed. Porto; 2006.

17. Masiero S. Thermal rehabilitation and osteoarticular diseases of the elderly. Aging Clin Exp Res 2007;20:189-94.

http://www.ncbi.nlm.nih.gov/pubmed/18594184

18. Fioravanti A, Cantarini L, Guidelli G, Galeazzi M. Mechanisms of action of spa therapies in rheumatic 
diseases: what scientific evidence is there? Rheumatology international 2011;31:1-8. http://www.ncbi.nlm.nih.gov/pubmed/21120502

19. Galzigna L, Ceschi-Berrini C, Moschin E, Tolomio C. Thermal mud-pack as an antiinflammatory treatment. Biomed Pharmacother 1998;52:408-9.

http://www.ncbi.nlm.nih.gov/pubmed/9856289

20. Gorchakova G, Pavlova E, Ruchkina A, Skridonenko A. [Mud treatment of patients with rheumatoid arthritis with an immunologic deficiency] [Abstract]. Vopr Kurortol Fizioter Lech Fiz Kult 1989:32-5 http://www.ncbi.nlm.nih.gov/pubmed/2603406

21. Grigor'eva V, Mamiliaeva D. [The use of low-temperature peloids in treating patients with rheumatoid arthritis (I)] [Abstract]. Vopr Kurortol Fizioter Lech Fiz Kult 1994:17-21. http://www.ncbi.nlm.nih.gov/pubmed/7709609

22. Grigor'eva V, Mamiliaeva D. [The use of low-temperature pelotherapy in the treatment of patients with rheumatoid arthritis (II)] [Abstract]. Vopr Kurortol Fizioter Lech Fiz Kult 1995:20-3. http://www.ncbi.nlm.nih.gov/pubmed/7785214

23. von Svarcová J, Hofta T, Kouba A, Trnavsky K, Zvárová J. [Effects on pain behavior of the foot using physioterapy in patients with rheumatoid arthritis] [Abstract]. Z Physioter 1990;42:109-12.

24. Sukenik S, Buskila D, Neumann L, Kleiner-Baumgarten A. Mud pack therapy in rheumatoid arthritis. Clin Rheumatol 1992;11:243-7. http://www.ncbi.nlm.nih.gov/pubmed/1617901

25. Codish S, Abu-Shakra M, Flusser D, Friger $\mathrm{M}$, Sukenik S. Mud compress therapy for the hands of patients with rheumatoid arthritis. Rheumatol Int2005;25:49-54.

http://www.ncbi.nlm.nih.gov/pubmed/14618372

26. Elkayam O, Wigler I, Tishler $\mathrm{M}$, et al. Effect of spa therapy in Tiberias on patients with rheumatoid arthritis and osteoarthritis. J Rheumatol 1991;18:1799-803.

http://www.ncbi.nlm.nih.gov/pubmed/1795315

27. Mustur D, Vesović-Potić V, VujasinovićStupar N, Ille T. [Beneficial effects of spa treatment on functional status and quality of life of patients with rheumatoid arthritis] [Abstract]. Srp Arh Celok Lek 2008;136:391-6. http://www.ncbi.nlm.nih.gov/pubmed/18959175

28. Stojanović S, Dimić A, Stamenković B, Stanković A, Nedović J. [Influence of balneophysical therapy on activity, functional capacity, and quality of life in patients with rheumatoid arthritis] [Abstract]. Srp Arh Celok Lek 2009;137:171-4.

http://www.ncbi.nlm.nih.gov/pubmed/19459564

29. Fabiani D, Partsch G, Casale R, Cerinic M. Rheumatologic aspects of mineral water. Clin Dermatol 1996;14:571-5. http://www.ncbi.nlm.nih.gov/pubmed/8960795

30. Routh H, Bhowmik K. Basic tenets of mineral water - a glossary of concepts relating to balneology, mineral water, and the spa. Clin Dermatol 1996;14:549-50.

31. Nasermoaddeli A, Kagamimori S. Balneotherapy in Medicine: A Review. Environ Health Prev Med 2005;10:171-9. http://www.ncbi.nlm.nih.gov/pubmed/21432136

32. Eversden L, Maggs F, Nightingale P, Jobanputra P. A pragmatic randomised controlled trial of hydrotherapy and land exercises on overall well being and quality of life in rheumatoid arthritis. BMC Musculoskelet Disord 2007;8:23. http://www.ncbi.nlm.nih.gov/pubmed/17331241

33. Hall J, Skevington S, Maddison P, Chapman K. A randomized and controlled trial of hydrotherapy in rheumatoid arthritis. Arthritis Care Res 1996;9:206-15. http://www.ncbi.nlm.nih.gov/pubmed/8971230

34. Hercogova J, Stanghellini E, Tsoureli-Nikita E, Menchini G. Inhibitory effects of Leopoldine spa water on inflammation caused by sodium lauryl sulphate. J Eur Acad Dermatol Venereol 2002;16:263-6. http://www.ncbi.nlm.nih.gov/pubmed/12195568

35. Peter A, Wagner H. [Changes in the immunological components of the blood during balneotherapy in patients with rheumatoid arthritis]. Z Gesamte Inn Med 1980;35:300-3. http://www.ncbi.nlm.nih.gov/pubmed/6157259

36. Bender T, Bariska J, Vághy R, Gomez R, Kovács I. Effect of balneotherapy on the antioxidant system - a controlled pilot study. Archives of medical research http://www.ncbi.nlm.nih.gov/pubmed/17174729

37. Marazziti D, Baroni S, Giannaccini G, et al. Thermal balneotherapy induces changes of the platelet serotonin transporter in healthy subjects. Progress in neuro-psychopharmacology \& biological psychiatry 2007;31:1436-9.

http://www.ncbi.nlm.nih.gov/pubmed/17689848

38. Schmid K, Kuwert T, Drexler H. Radon in Indoor Spaces-An Underestimated Risk Factor for Lung Cancer in Environmental Medicine. Dtsch Arztebl Int 2010;107:730-2. http://www.ncbi.nlm.nih.gov/pubmed/20386676

39. Franke A, Reiner L, Resch K. Long-term benefit of radon spa therapy in the rehabilitation of rheumatoid arthritis: a randomised, double-blinded trial. Rheumatology international 2007;27:703-13. http://www.ncbi.nlm.nih.gov/pubmed/17203297

40. Franke A, Reiner L, Pratzel H, Franke T, Resch $\mathrm{K}$. Long-term efficacy of radon spa therapy in rheumatoid arthritis - a randomized, sham-controlled study and follow-up. Rheumatology (Oxford) 2000;39:894-902.

http://www.ncbi.nlm.nih.gov/pubmed/10952746

41. Verhagen A, Bierma-Zeinstra S, Boers M, et al. Balneotherapy for rheumatoid arthritis (Review). Cochrane Database Syst Rev 2003:CD000518. http://www.ncbi.nlm.nih.gov/pubmed/14583923

42. Günther R, Kolarz G, Thumb N, Grabner H. [The implementation of a computerized documentation system for the evaluation of spa therapy in patients with rheumatoid arthritis (author's transl)] [Abstract]. Wien 
Klin Wochenschr 1976;88:84-7.

http://www.ncbi.nlm.nih.gov/pubmed/960708

43. Steiner F, Valkenburg $H$, van de Stadt R,

Stoyanova-Drenska M, Zant J. [Balneology treatment of patients with rheumatoid arthritis]. Ned Tijdschr Geneeskd 1979;123:661-4. http://www.ncbi.nlm.nih.gov/pubmed/431747

44. Sukenik S, Neumann L, Buskila D, Kleiner-Baumgarten A, Zimlichman S, Horowitz J. Dead Sea bath salts for the treatment of rheumatoid arthritis. Clin Exp Rheumatol 1990;8:353-7. http://www.ncbi.nlm.nih.gov/pubmed/2397624

45. Landewé R, Peeters R, Verreussel R, Masek $\mathrm{B}$, Thè $\mathrm{H}$. [No difference in effectiveness measured between treatment in a thermal bath and in an exercise bath in patients with rheumatoid arthritis]. Ned Tijdschr Geneeskd 1992;136:173-6. http://www.ncbi.nlm.nih.gov/pubmed/1736128

46. Sukenik S, Neumann L, Flusser D, KleinerBaumgarten A, Buskila D. Balneotherapy for rheumatoid arthritis at the Dead Sea. Isr J Med Sci 1995;31:210-4.

http://www.ncbi.nlm.nih.gov/pubmed/7721556

47. Grabski M, Wozakowska-Kapłon B, Kedziora J. [Hydrogen sulfide water balneum effect on erythrocyte superoxide dismutase activity in patients with rheumatoid arthritis--in vitro study] [Abstract]. Przegl Lek 2004;61:1405-9. http://www.ncbi.nlm.nih.gov/pubmed/15850338

48. Marković M, Majkić-Singh N, Ignjatović S. Beneficial effects of cellular stress response in traditional spa treatment of rheumatoid arthritis. Clin Lab 2009;55:235-41. http://www.ncbi.nlm.nih.gov/pubmed/19728558

49. Behrend T. The balneotherapy of rheumatoid arthritis. Rheumatol Rehabil 1979;Suppl:86-7.

http://www.ncbi.nlm.nih.gov/pubmed/441640

50. Françon A, Forestier R. [Spa therapy in rheumatology. Indications based on the clinical guidelines of the French National Authority for health and the European League Against Rheumatism, and the results of 19 randomized clinical trials]. Bull Acad Natle Méd 2009; 193:1345-58.

http://www.ncbi.nlm.nih.gov/pubmed/20120164

51. Forestier R, André-Vert J, Guillez P, et al. Non-drug treatment (excluding surgery) in rheumatoid arthritis: Clinical practice guidelines. Joint Bone Spine 2009;76:691-8. http://www.ncbi.nlm.nih.gov/pubmed/19945896

52. Hurkmans E, van der Giesen F, Bloo H, et al. Physiotherapy in rheumatoid arthritis: development of a practice guideline. Acta Reumatol Port 2011;36:146-58. http://www.ncbi.nlm.nih.gov/pubmed/21841734

53. Hurkmans E, Jones A, Li L, Vlieland $\mathrm{T}$. Quality appraisal of clinical practice guidelines on the use of physiotherapy in rheumatoid arthritis: a systematic review. Rheumatology (Oxford) 2011;50:1879-88.

http://www.ncbi.nlm.nih.gov/pubmed/21176795
54. Françon A, Jeambrun P, Forestier R. [Réflexions sur la durée médicale des cures thermales: expérience des pays étrangers et niveaux de preuves scientifiques]. Press Therm Climat 2008;145:41-59.

55. Munteanu C. Therapeutic mineral water. Balneo-Research Journal 2011;2:52. http://dx.doi.org/10.12680/balneo.2011.1011

56. Vlieland T. Non-drug care for RA - is the era of evidence-based practice approaching? Rheumatology (Oxford) 2007;46:1397-404. http://www.ncbi.nlm.nih.gov/pubmed/17586864

57. Michalsen A, Ludtke R, Buhring M, Spahn G, Langhorst J, Dobos G. Thermal hydrotherapy improves quality of life and hemodynamic function in patients with chronic heart failure. Am Heart J 2003;146:1-6. http://www.ncbi.nlm.nih.gov/pubmed/14564334

58. Olah M, Koncz A, Feher J, et al. The effect of balneotherapy on antioxidant, inflammatory, and metabolic indices in patients with cardiovascular risk factors (hypertension and obesity)--a randomised, controlled, follow-up study. Contemp Clin Trials 2011;32:793-801.

http://www.ncbi.nlm.nih.gov/pubmed/21763463

59. Shaw K, Zochling J, Winzenberg $T$. Nonpharmacological interventions for rheumatoid arthritis. Aust Fam Physician 2007;36:840-1. http://www.ncbi.nlm.nih.gov/pubmed/17925906

60. Gutenbrunner C, Bender T, Cantista P, Karagulle Z. A proposal for a worldwide definition of health resort medicine, balneology, medical hydrology and climatology. Int J Biometeorol 2010;54:495-507. http://www.ncbi.nlm.nih.gov/pubmed/20532921

61. Oosterveld F, Rasker J, Floors M, et al. Infrared sauna in patients with rheumatoid arthritis and ankylosing spondylitis. A pilot study showing good tolerance, short-term improvement of pain and stiffness, and a trend towards long-term beneficial effects. Clin Rheumatol 2009;28:29-34.

http://www.ncbi.nlm.nih.gov/pubmed/18685882 